\title{
Five-year experience with donation after cardiac death kidney transplantation in a Canadian transplant program: Factors affecting outcomes
}

\author{
Michael Moser, MD, FRCSC;, Michael Sharpe, MD, FRCPC;, Corinne Weernink, Harrison Brown, Thomas \\ McGregor, MD, FRCSC, ${ }^{*}{ }^{*}$ Andrew A. House, MD, FRCPC, MSc, ${ }^{*}$ Patrick P. Luke, MD, FRCSC ${ }^{*}$
}

*Multi-Organ Transplant Program, London Health Sciences Centre, Schulich School of Medicine, Western University, London, ON; ‘Saskatchewan Renal Transplant Program, St. Paul's Hospital, Saskatoon, SK; §Manitoba Transplant Program, Health Sciences Centre, Winnipeg, MB

See related article on page 453.

Cite as: Can Urol Assoc J 2012;6(6):448-52. http://dx.doi.org/10.5489/cuaj.12104

\section{Abstract}

Background: Donation after cardiac death (DCD) has led to an increase of up to $40 \%$ in the number of kidney transplants in some programs. Unfortunately, the increase in warm ischemic time results in higher rates of delayed graft function (DGF). The purpose of our study was to examine our initial 5-year experience with DCD kidney transplantation and to determine the factors involved in early postoperative function and function at 1 year.

Methods: This retrospective study included a review of the recipient and donor charts of 63 DCD kidneys retrieved and transplanted by the London Multi-Organ Transplant Program between July 2006 and October 2011. Comparisons were carried out between our early ( $n=31$, July 2006 to January 2009) and our recent experience $(n=32$, March 2009 to October 2011). DGF and creatinine clearance at 3, 7 and 365 days were examined with regression analyses. Results: DGF was seen in $65 \%$ of transplanted kidneys. Mean creatinine clearance $(\mathrm{CrCl})$ at 1 year was $66.7 \mathrm{~mL} / \mathrm{min}$. Low pretransplant recipient daily urine output was the most statistically significant predictor of DGF in multivariate analysis $(p<0.001)$. In comparisons between our early and more recent results, improvements were noted in time from asystole to flush (16.0 vs. 12.0 minutes, $p=0.003$ ), while cold ischemic time increased (464 vs. 725 minutes, $p=0.006$ ). Experience contributed to a significant reduction in hospital length of stay (16 vs. 13 days, $p=0.035$ ) and improved early renal function $(\mathrm{CrCl}$ at 3 days $7.8 \mathrm{vs} .11 .9 \mathrm{~mL} /$ $\min , p=0.027)$. The use of machine cold perfusion and higher recipient preoperative daily urine output predicted improved early renal function, while increasing donor age predicted poorer function at 1 year.

Discussion: Despite early DGF, our results justify the continued transplantation of kidneys from DCD donors.

\section{Introduction}

In the early period of transplantation in the 1960s, the retrieval of organs for transplantation could only occur after the cessation of cardiac activity (cardiac death), as brain death was not yet recognized. The only alternative was to obtain a kidney from a living relative. In 1968, the Ad Hoc committee of Harvard Medical School ${ }^{1}$ arrived at a definition for brain death (currently designated as Neurological Determination of Death $[N D D]^{2}$ ) which allows retrieval of organs that are perfused until the time of procurement. As a result, the organs obtained for transplant were of much better quality. As there were few transplant programs at the time, NDD donors appeared to provide ample organs for transplantation and the use of organs from donation after cardiac death (DCD) donors ceased in all but a few programs in the United States, although some jurisdictions outside North America, particularly in Europe, continued to use DCD donor organs for a many of their deceased donor transplants.

At the turn of the new millennium, the gap between the number of people awaiting transplantation and the number of organs available was growing and programs were challenged to find ways to increase the number of organs available for transplant. The retrieval of organs from donors after cardiac death was re-examined. DCD does not actually represent a new way of obtaining organs from deceased donors, but rather a return to an original approach to organ procurement.

Early organ function could be compromised with DCD transplantation due to a prolonged warm ischemic time associated with withdrawal of life support, the subsequent declaration of cardiac death, and the time of cannulation for flushing and cooling. Therefore, it is important to carefully assess factors that affect immediate- and long-term DCD outcomes. We hypothesize that early kidney function is affected by warm ischemic time, blood pressure during 
the withdrawal process, and the use of pulsatile perfusion machines during organ storage. We also believe there is a significant learning curve in managing the DCD donor/ organ and that delayed graft function (DGF) rates fall with increasing clinical experience.

\section{Methods}

Ethics approval for a retrospective chart review was obtained from the Western University Health Sciences Research Ethics Board. Between July 2006 and October 2011, 72 kidneys were retrieved from DCD donors by the London Multi-Organ Transplant Program retrieval team. Three were used in simultaneous kidney-pancreas transplants and 2 pairs were used for en-bloc transplantation. Two kidneys were sent to another program for implantation. The remaining 63 kidneys that were transplanted as a single-organ transplant at the London Health Sciences Centre were included in our analysis.

A database was created in Excel 2007 (Microsoft, Richmond, WA) after review of each patient's medical record. We also reviewed the initial consultation for transplant assessment performed by the transplant nephrologist and transplant surgeon. Pre-transplant urine daily output was estimated as 15, 125, 250, 1000 and $2000 \mathrm{~mL}$, respectively, recognizing that these are crude estimates. Donor information was obtained from the detailed electronic database, which included hemodynamic data recorded from the time of withdrawal of life support to the initiation of flushing of organs. A "no-touch" time of 5 minutes from the time of cessation of antegrade blood flow is standard at our institution. ${ }^{3}$ Machine cold perfusion, when used, was with the LifePort Pulsatile Flow Kidney Transporter (Organ Recovery Systems, Chicago, IL), with Kidney Perfusion Solution-1 (KPS-1) solution at $4^{\circ} \mathrm{C}$.

All but 2 patients were induced with thymoglobulin. Maintenance immunotherapy included tacrolimus, mycophenolate mofetil and prednisone. DGF was defined as the need for dialysis in the first week post-transplant, while slow graft function (SGF) was defined as serum creatinine $>265 \mu \mathrm{mol} / \mathrm{L}$ on day 5 , without a need for dialysis. ${ }^{4}$ Creatinine clearance was calculated using the CockcroftGault equation (for stable creatinine) or the Jeliffe equation ${ }^{5}$ for non-steady-state creatinine, such as one would expect in the first postoperative week.

\begin{tabular}{|c|c|}
\hline Successful retrievals & $36 / 41(87.8 \%)$ \\
\hline Overall graft survival & $60 / 63(95.2 \%)$ \\
\hline Overall patient survival & $62 / 63(98.4 \%)$ \\
\hline One-year graft survival & $54 / 56(96.4 \%)$ \\
\hline One-year patient survival & $55 / 56(98.2 \%)$ \\
\hline
\end{tabular}

Our main outcomes of interest were creatinine clearance on days 3, 7, 30 and 365 and DGF. Univariate analysis was carried out and factors with a $p$ value of $\leq 0.20$ were then entered into a multivariate regression analysis model to determine factors associated with creatinine clearance at the various times. Logistic regression was used for DGF. We also compared our early ( $n=31$, from July 2006 to January 2009) versus recent experience $(n=32$, from March 2009 to October 2011) to identify trends or improvements in outcomes as we learned from our program's DCD experience.

Data were analysed using the Student's t-Test or Chisquared test as appropriate and the Mann-Whitney $U$ test and Spearman's correlation were used for non-parametric data. Multivariate regressionand logistic regression analyses were calculated using SPSS 20 (SAS institute, Cary, NC).

\section{Results}

\section{Graft function}

We tallied overall outcomes (Table 1). DGF was seen in 65\% of transplanted kidneys and SGF in $15.9 \%$, while primary nonfunction was not observed. Most often, the indication for dialysis was fluid overload (Table 2). We compared the features of the grafts that exhibited early and the DGF (Table 3). Retrieval factors were important; the total time the donor had a mean arterial pressure (MAP) less than $55 \mathrm{mmHg}$ during the withdrawal period was significant $(p=0.049)$, while there was a trend towards significance in terms of the time from asystole to flush $(p=0.07)$ and time from withdrawal to asystole $(p=0.063)$. Interestingly, of all the factors, pre-transplant (i.e., native kidney) daily urine output shows the most significant difference, and the significance of this factor alone persists when logistic regression analysis was carried out.

\section{Early vs. recent experience with DCD kidney transplantation}

Aside from the difference in gender distribution among donors in the two groups, there was no difference in the donor characteristics (Table 4). Retrieval times appeared

\begin{tabular}{|c|c|}
\hline Delayed graft function & $41 / 63(65.1 \%)$ \\
\hline Slow graft function & $10 / 63(15.9 \%)$ \\
\hline Primary non-function & 0 \\
\hline $\begin{array}{l}\text { Indications for dialysis } \\
\text { - } \quad \text { Fluid overload } \\
\text { - Hyperkalemia } \\
\text { - "Uremia" or none listed }\end{array}$ & $\begin{array}{l}18(44 \%) \\
10(24 \%) \\
17(42 \%)\end{array}$ \\
\hline $\mathrm{CrCl}$ at one month, median (IQR) & $42.5 \mathrm{~mL} / \mathrm{min}(33.4,69.6)$ \\
\hline $\mathrm{CrCl}$ at one year, median (IQR) & $66.7 \mathrm{~mL} / \min (56.4,78.5)$ \\
\hline
\end{tabular}




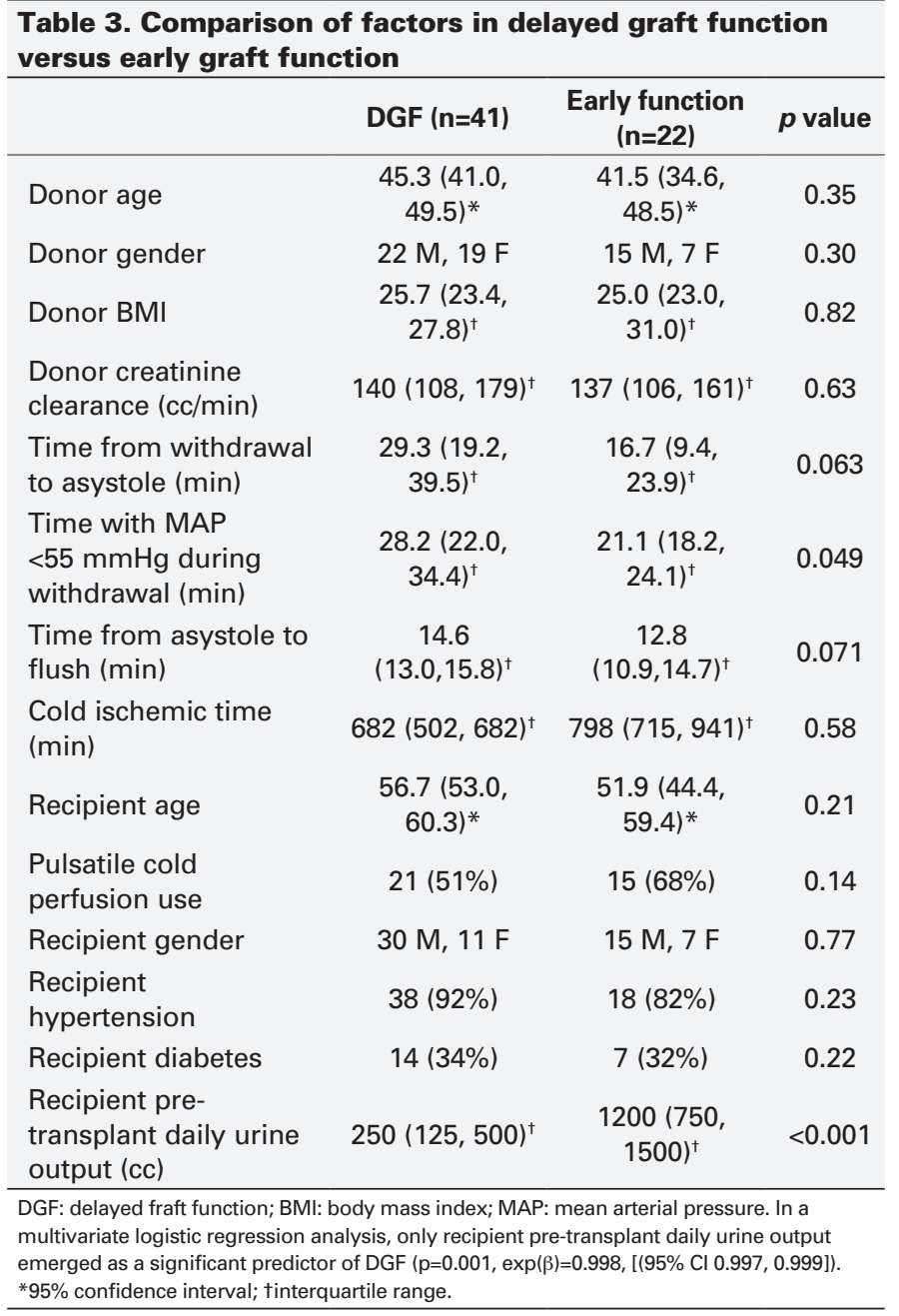

to change with our more recent experience. Decreases were noted in terms of the time with MAP under $55 \mathrm{mmHg}$ and time from asystole to flush, while cold ischemic time increased. The use of the cold pulsatile perfusion was introduced to the program midway through the early phase of our program and occurred in $26 \%$ (early) versus $81 \%$ (late) of kidney transplants. Recipient characteristics did not change and although there was a trend towards fewer biopsies being done in the recent time period, this did not achieve statistical significance.

Experience contributed to a significant reduction in hospital length of stay (16 vs. 13 days) and in early renal function (creatinine clearance), without a significant change in the rate of DGF (Table 5). The improvement in creatinine clearance on day 3 was studied (Table 6) using univariate analysis; subsequently, a multivariate analysis model was constructed. The use of pulsatile cold perfusion and recipient pre-transplant daily urine output emerged as significant predictive factors. A similar analysis was done for creatinine clearance on day 7 , with similar results (data not shown).
To examine factors involved in longer-term outcomes, we studied creatinine clearance at 1 year in a similar manner (Table 7). The only factor that emerged as a significant predictor in multivariate analysis was donor age.

\section{Cold pulsatile perfusion}

As discussed above, cold pulsatile perfusion emerged as an independent predictor of improved early creatinine clearance (Fig. 1).

\section{Discussion}

A review of our DCD donor kidney transplants since inception of our DCD program in 2006 revealed that 3-month and 1-year graft survival and function were excellent, despite a high DGF rate. This is consistent with the experience of other DCD transplant series. ${ }^{6,7}$ In this population with high DGF rates, the most frequent indication for early dialysis was "fluid overload." Interestingly, we also noted that an increased pre-transplant daily urine output strongly predicted avoidance of DGF and was associated with increased early creatinine clearance. To our knowledge, pre-transplant

\begin{tabular}{|c|c|c|c|}
\hline & Early $(n=31)$ & Recent (n=32) & $p$ value \\
\hline Donor age & $\begin{array}{l}43.4(38.0 \\
48.8)^{*}\end{array}$ & $\begin{array}{c}44.5(39.4 \\
49.6)^{*}\end{array}$ & 0.77 \\
\hline Donor gender & $9 \mathrm{M}, 22 \mathrm{~F}$ & $28 \mathrm{M}, 4 \mathrm{~F}$ & $<0.001$ \\
\hline Donor BMI & $\begin{array}{c}24.8(23.4, \\
26.8)^{\dagger}\end{array}$ & $\begin{array}{c}27.4(22.9, \\
31.4)^{\dagger}\end{array}$ & 0.42 \\
\hline $\begin{array}{l}\text { Donor creatinine } \\
\text { clearance }\end{array}$ & $133(122,171)^{\dagger}$ & $\begin{array}{c}140(101 \\
176)^{\dagger}\end{array}$ & 0.69 \\
\hline $\begin{array}{l}\text { Time from withdrawal } \\
\text { to asystole (min) }\end{array}$ & $13.0(9.5,33.5)^{\dagger}$ & $\begin{array}{c}12.0(10.8 \\
15.3)^{\dagger}\end{array}$ & 0.41 \\
\hline $\begin{array}{l}\text { Time with MAP } \\
<55 \mathrm{mmHg} \text { during } \\
\text { withdrawal (min) }\end{array}$ & $\begin{array}{c}25.0(18.0 \\
34.5)^{\dagger}\end{array}$ & $\begin{array}{c}18.0(15.8 \\
22.3)^{\dagger}\end{array}$ & 0.003 \\
\hline $\begin{array}{l}\text { Time from asystole to } \\
\text { flush (min) }\end{array}$ & $\begin{array}{c}16.0(13.0 \\
17.0)^{\dagger}\end{array}$ & $\begin{array}{c}12.0(11.0 \\
15.3)^{\dagger}\end{array}$ & 0.003 \\
\hline $\begin{array}{l}\text { Cold ischemic time } \\
\text { (min) }\end{array}$ & $464(261,770)^{\dagger}$ & $\begin{array}{c}725(600 \\
894)^{\dagger}\end{array}$ & 0.006 \\
\hline $\begin{array}{l}\text { Warm ischemic time } \\
\text { (min) }\end{array}$ & $\begin{array}{c}26.0(24.5, \\
48.0)^{\dagger}\end{array}$ & $\begin{array}{c}24.0(22.0, \\
27.3)^{\dagger}\end{array}$ & 0.19 \\
\hline $\begin{array}{l}\text { Pulsatile cold perfusion } \\
\text { used }\end{array}$ & $8 / 31$ (25.8\%) & $\begin{array}{c}26 / 32 \\
(81.3 \%)\end{array}$ & $<0.001$ \\
\hline Recipient age & $\begin{array}{l}54.2(49.0, \\
59.5)^{*}\end{array}$ & $\begin{array}{l}55.8(50.9, \\
60.7)^{*}\end{array}$ & 0.67 \\
\hline Recipient gender & $23 \mathrm{M}, 8 \mathrm{~F}$ & $27 \mathrm{M}, 10 \mathrm{~F}$ & 0.62 \\
\hline Recipient hypertension & $28(90.3 \%)$ & $28(87.5 \%)$ & 0.96 \\
\hline Recipient diabetes & $11(35.5 \%)$ & $10(31.3 \%)$ & 0.72 \\
\hline
\end{tabular}

BMI: body mass index; MAP: mean arterial pressure; M: male; F: female; ${ }^{9} 95 \%$ confidence interval, tinterquartile range. 


\begin{tabular}{|c|c|c|c|}
\hline & Early (n=31) & Recent (n=32) & $p$ value \\
\hline Successful retrievals & 17 / 18 (94\%) & 19 / 23 (83\%) & 0.40 \\
\hline Slow graft function & 4 / 31 (13\%) & 6 / $32(19 \%)$ & 0.53 \\
\hline Delayed graft function & 22 / $31(71 \%)$ & 19 / 32 (59\%) & 0.33 \\
\hline Length of stay (days) & $16(12,18)$ & $13(9,15)$ & 0.035 \\
\hline $\begin{array}{l}\text { Biopsy during initial } \\
\text { admission }\end{array}$ & $21 / 31(69 \%)$ & $16 / 32(50 \%)$ & 0.15 \\
\hline $\begin{array}{l}\text { Creatinine clearance at } \\
3 \text { days }(\mathrm{mL} / \mathrm{min})\end{array}$ & $7.8(3.6,14.3)^{\dagger}$ & $\begin{array}{c}11.9(8.1 \\
18.0)^{\dagger}\end{array}$ & 0.027 \\
\hline $\begin{array}{l}\text { Creatinine clearance at } \\
7 \text { days }(\mathrm{mL} / \mathrm{min})\end{array}$ & $\begin{array}{c}11.3(6.0 \\
20.5)^{\dagger}\end{array}$ & $\begin{array}{c}16.6(9.9 \\
26.7)^{\dagger}\end{array}$ & 0.13 \\
\hline $\begin{array}{l}\text { Creatinine clearance at } \\
30 \text { days }(\mathrm{mL} / \mathrm{min})\end{array}$ & $\begin{array}{c}42.5(34.3 \\
69.5)^{\dagger}\end{array}$ & $\begin{array}{c}42.8(33.4 \\
69.5)^{\dagger}\end{array}$ & 0.84 \\
\hline $\begin{array}{l}\text { Creatinine clearance at } \\
365 \text { days }(\mathrm{mL} / \mathrm{min})\end{array}$ & $\begin{array}{c}66.4(57.5 \\
77.6)^{\dagger} \\
\end{array}$ & $\begin{array}{c}67.0(56.3 \\
79.2)^{\dagger} \\
\end{array}$ & 0.80 \\
\hline
\end{tabular}

urine output as a predictor of need for dialysis post-transplant has not been reported elsewhere. Taken together, the residual ability of the native kidneys to affect overall fluid balance may critically affect the need for dialysis in DCD renal transplant recipients with limited initial renal function.

Additionally, improvements in perioperative donor and organ management, including a decrease in time from asystole to flush and an increased use of pulsatile cold perfusion in our most recent cases, improved early transplant outcomes. The aforementioned factors and likely our greater comfort with DCD transplant recipients led to a reduction in length of hospital stays for the recipients along with a trend

\begin{tabular}{|c|c|c|c|c|}
\hline \multirow[b]{2}{*}{ Factor } & \multirow{2}{*}{$\begin{array}{c}\text { Univariate } \\
p \text { value }\end{array}$} & \multicolumn{3}{|c|}{ Multivariate } \\
\hline & & $p$ value & $\beta$ & $95 \% \mathrm{Cl}$ \\
\hline Donor age & 0.09 & 0.007 & -0.69 & $\begin{array}{l}(-1.16 \\
-0.22)\end{array}$ \\
\hline Donor BMI & 0.40 & & & \\
\hline $\begin{array}{l}\text { Donor creatinine } \\
\text { clearance }\end{array}$ & 0.78 & & & \\
\hline $\begin{array}{l}\text { Time from withdrawal to } \\
\text { asystole }\end{array}$ & 0.24 & & & \\
\hline $\begin{array}{l}\text { Time with MAP }<55 \\
\mathrm{mmHg}\end{array}$ & 0.68 & & & \\
\hline $\begin{array}{l}\text { Time from asystole to } \\
\text { flush }\end{array}$ & 0.89 & & & \\
\hline Cold ischemic time & 0.15 & & & \\
\hline Warm ischemic time & 0.28 & & & \\
\hline $\begin{array}{l}\text { Pulsatile cold perfusion } \\
\text { use }\end{array}$ & 0.43 & & & \\
\hline $\begin{array}{l}\text { Recipient pre-transplant } \\
\text { daily urine output (cc) }\end{array}$ & 0.42 & & & \\
\hline
\end{tabular}

Table 6. Analysis of factors involved in improved creatinine clearance on postoperative day 3

\begin{tabular}{|c|c|c|c|c|}
\hline \multirow[b]{2}{*}{ Factor } & \multirow{2}{*}{$\begin{array}{c}\text { Univariate } \\
p \text { value }\end{array}$} & \multicolumn{3}{|c|}{ Multivariate } \\
\hline & & $p$ value & $\beta$ & $95 \% \mathrm{Cl}$ \\
\hline Donor age & 0.70 & & & \\
\hline Donor BMI & 0.34 & & & \\
\hline $\begin{array}{l}\text { Donor creatinine } \\
\text { clearance }\end{array}$ & 0.58 & & & \\
\hline $\begin{array}{l}\text { Time from withdrawal to } \\
\text { asystole }\end{array}$ & 0.70 & & & \\
\hline $\begin{array}{l}\text { Time with MAP } \\
<55 \mathrm{mmHg}\end{array}$ & 0.50 & & & \\
\hline $\begin{array}{l}\text { Time from asystole to } \\
\text { flush }\end{array}$ & 0.014 & & & \\
\hline Cold ischemic time & 0.19 & & & \\
\hline Warm ischemic time & 0.30 & & & \\
\hline $\begin{array}{l}\text { Pulsatile cold perfusion } \\
\text { use }\end{array}$ & 0.008 & 0.018 & 7.39 & $\begin{array}{l}(1.35 \\
13.43)\end{array}$ \\
\hline $\begin{array}{l}\text { Recipient pre-transplant } \\
\text { daily urine output (cc) }\end{array}$ & 0.051 & 0.001 & 0.008 & $\begin{array}{l}(0.004 \\
0.013)\end{array}$ \\
\hline
\end{tabular}

towards fewer biopsies. The pulsatile perfusion machines were not used in our program until mid-2008. It was our institution's intention to use pulsatile perfusion in all DCD kidneys with a predicted cold ischemia time of 6 hours or greater. Indeed, the cold ischemic time for kidneys that were not placed on the pump was significantly shorter (8.9 hours) compared to kidneys that were placed on the pump (12.7 hours, $p=0.005$ ). With the addition of pulsatile perfusion pumps, and increasing comfort level with these organs, our late versus early data demonstrated increased cold ischemic time. In the early phase, all DCD kidneys were transplanted as soon as possible, even if this meant calling in

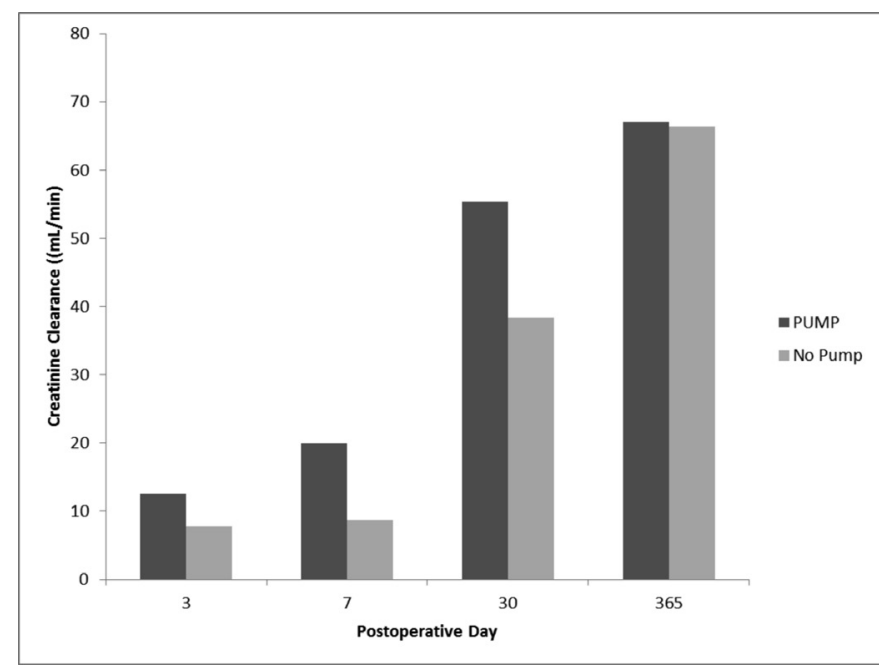

Fig. 1. Creatinine clearance on days $3,7,30$, and 365 for donation after cardiac death kidneys preserved with static cold preservation ('No Pump') versus pulsatile cold perfusion ('PUMP'). 
Moser et al.

a second operating room team to transplant kidneys simultaneously. With experience, DCD renal transplants were prioritized in the same manner as standard criteria kidneys. It was reassuring that despite increased cold ischemic times, early graft function results continued to improve.

In terms of longer-term graft function, among the factors analyzed, only donor age was found to influence graft function at 1 year. This is in keeping with inferior long-term results being observed for Expanded Criteria Donor-DCD (ECD-DCD) kidneys by our institution and other programs. ${ }^{8,9}$

Based on our comparison of the early versus the recent periods in our program, we have identified areas that we have improved upon. Improvements in the time to insert the aortic cannula and flush of even a few minutes may affect early function. We have found that clearly defining very specific roles of everyone in the operating room (often from more than one transplant team) and having a "surgeon's toolbox" to reduce time spent asking for instruments in those first crucial minutes likely contributed to a time savings.

Our study was limited by its retrospective nature. Given that 2 or 3 years may pass between the original medical assessment and the transplant suggests that some of the preoperative data may not actually reflect the state of the patient's kidney function at the time of the transplant. As well, measuring outcomes based on the basis of DGF rates has its limitations. In some cases, the indications for dialysis were somewhat vague (i.e., uremia).

\section{Conclusion}

It is important to note that these 63 kidneys retrieved from DCD donors represent 63 transplants that may never have occurred prior to the implementation of our DCD program. This represents a $25 \%$ increase in the total number of kidneys available for transplant over the last 5 years at our centre. Despite early DGF, our results justify the continued transplantation of kidneys from DCD donors, given the very good long-term function.

Competing interests: None declared.

This paper has been peer-reviewed.

\section{References}

1. A definition of irreversible coma: report of the Ad Hoc committee of the Harvard Medical School to examine the definition of brain death. JAMA 1968:5:205:337-40.

2. Canadian Congress Committee on brain death. Death and brain death: a new formulation for Canadian medicine. CMAJ 1988; 138:405-6

3. Shemie SD, Baker AJ, Knoll G, et al. National recommendations for donation after cardiocirculatory death in Canada. CMAJ 2006;175(8 Supp): S1-24. http://dx.doi.org/10.1503/cmaj.060895

4. Humar A, Johnson EM, Payne WD, et al. Effect of initial Slow Graft Function on renal allograft rejection and survival. Clin Transplant 1997;11:623-7.

5. Jeliffe R. Estimation of creatinine clearance in patients with unstable renal function, without a urine specimen. Am J Nephrol 2002;22:320-4. htrp://dx.doi.org/10.1159/000065221

6. Ledinh H, Weekers L, Bonvoisin C, et al. Results of kidney transplantation from controlled donors after cardio-circulatory death: a single center experience. Transpl Int 2011;25:201-6. http://dx.doi. org/10.1111/i.1432-2277.2011.01402.x

7. Cooper J, Chin T, Krieger N, et al. Donation after cardiac death: The University of Wisconsin experience with renal transplantation. Am J Transp/ 2004;4:1490-6. http://dx.doi.org/10.1111/j.16006143.2004.00531.x

8. Farney AC, Hines MH, Al-Gezawi S, et al. Lessons learned from a single center's experience with 134 donation after cardiac death donor kidney transplants. J Am Coll Surg 2011;212:440-51. http://dx.doi. org/10.1016/i.jamcollsurg.2010.12.033

9. Saidi RF, Elias N, Kawai T, et al. Outcome of kidney transplantation using expanded criteria donors and donation after cardiac death kidneys: realities and costs. Am J Transplant 2007;7:2769-74. http:// dx.doi.org/10.1111/i.1600-6143.2007.01993.x

Correspondence: Dr. Patrick P. Luke, London Health Sciences Centre,Schulich School of Medicine, Western University, 339 Windermere Rd, London, ON N6A 5A5; fax: 519-663-3858; patrick.luke@hsc.on.ca 